\title{
STIGMASTANE-STEROID FROM THE BARK OF Chisocheton lasiocarfus (Meliaceae)
}

\author{
Nurlelasari $^{1}$, Fajar Fauzi Abdullah ${ }^{1}$, Nadya Thufailah ${ }^{1}$, Rani Maharani ${ }^{1,2}$, Desi Harneti ${ }^{1}$, Ace \\ Tatang Hidayat ${ }^{1,2}$ and Unang Supratman ${ }^{1,2^{*}}$ \\ ${ }^{1}$ Department of Chemistry, Faculty of Mathematics and Natural Sciences, Universitas Padjadjaran, \\ Jalan Raya Bandung-Sumedang Km 21, Jatinangor 45363, Sumedang \\ ${ }^{2}$ Central Laboratory of Universitas Padjadjaran, Jalan Raya Bandung-Sumedang Km 21, Jatinangor \\ 45363, Sumedang \\ *E-mail: unang.supratman@unpad.ac.id
}

\begin{abstract}
Stigmastan-steroid, stigma-4-ene-3-on (1) has been isolated from the bark of Chisocheton lansiocarpus. The chemical structure of stigmastan-steroid was identified based on spectroscopic data and by comparison of spectral data obtained previously. The discovery of stigma-4-ene-3-on in C. lansiocarpus was shown in this study for the first time.
\end{abstract}

Keywords: Chisocheton lansiocarpus, Meliaceae., stigmastan-steroid, stigma-4-ene-3-on

\section{INTRODUCTION}

Phytosterols are a subgroup of the steroids, as an important class of bioorganic molecules, widespread in plants, animals, marines as well as fungi and have similarity to cholesterol in structure (Saeidnia et al., 2014), including $\beta$-sitosterol, campesterol, stigmasterol and cycloartenol (Ostlund, 2002). Phytosterols, especially $\beta$ sitosterol, reported have interesting activity including anti-inflammatory (Prieto et al., 2006), inducing apoptosis (Chai et al., 2008; Park et al., 2007; Ju et al., 2004), chemoprotective or chemopreventive effects (Ovesna et al., 2004), hypocholesterolemic (Zak et al., 1990), angiongenic effect (Moon et al., 1999), antidiabetic (Gupta et al., 2011; Jamaluddin et al., 1994; Radika et al., 2013), and anti-oxidant (Baskar et al., 2012; Vivancos and Moreno, 2005).

Chisocheton genus, the second largest genus of the Meliaceae family, consists of more than 50 species and distributes in Nepal, India, Myanmar, South China, Thailand, Indonesia, Malaysia, and Papua New Guinea (Vossen and Umali, 2002). Previous phytochemical studies on Chisochetonplantsreported the presence of compounds with interesting biological activities including insecticidal limonoid (Roy and Sarat, 2004), antifungal meliacin-type compounds (Bordoloi et al., 1993), spermidine alkaloids (Tzouros et al., 2004), sesquiterpenoids (Phongmaykin et al., 2008), dammarane-type triterpenoids (Inada et al., 1993; Phongmaykin et al., 2008), tirucallane-type triterpenoids (Zhang et al., 2012; Yang et al., 2011), apo-tirucallane-type triterpenoids (Zhang et al., 2012), limonoids (Maneerat et al., 2008; Laphookhieo et al., 2008; Mohamad et al., 2009; Yang et al., 2009; Najmuldeen et al., 2010; Wong et al., 2011) and steroidsandphenolics(Phongmaykin et al., 2008).

As part of our studies on novelly occuring compounds from Indonesia Chisocheton plants, herein we isolated and determine the chemical structure stigmastane-steroid from the stem bark of Chisocheton lasiocarfus that have yet to be reported before.

\section{MATERIAL AND METHODS}

\section{General Experimental Procedure}

The IR spectra were recorded on a PerkinElmer 1760X FT-IR in KBr. Mass spectra were 
obtained with a Water Qtof HR-MS XEV ${ }^{\text {otm }}$ mass spectrometer. ${ }^{1} \mathrm{H}-$ and ${ }^{13} \mathrm{C}-\mathrm{NMR}$ spectra were obtained with a JEOL JNM A-500 spectrometer using TMS as an internal standard. Chromatographic separations were carried out on silica gel 60 andocta desyl silane (ODS, Fuji Silysia). TLC plates were precoated with silica gel $\mathrm{GF}_{254}$ (Merck, $0.25 \mathrm{~mm}$ ), RP-18 (Merck, 0.25 $\mathrm{mm}$ ), and detection was achieved by spraying with $10 \% \mathrm{H}_{2} \mathrm{SO}_{4}$ in ethanol, followed by heating.

\section{Plant material}

The bark of $C$. lasiocarfuswas collected in Bogor Botanical Garden, Bogor, Indonesia in June 2015. The plant was identified by the staff of the Bogoriense Herbarium, Bogor, Indonesia and a voucher specimen was deposited at the herbarium.

\section{Plant extraction}

Dried ground bark of C. lasiocarfus (4.1 $\mathrm{kg}$ ) was extracted with methanol in room temperatur. Evaporation of the methanol extract in reduced pressure to produce the dark brown residue (209 g). The dark brown residue dissolved in water (1:1) and successively partitioned with $n$ hexane, EtOAc, and $\mathrm{MeOH}$. Evaporation resulted in the crude extracts of $n$-hexane (10.5 g), EtOAc $(20.0 \mathrm{~g})$, and $n$-BuOH $(50.0 \mathrm{~g})$, respectively. The EtOAc extract $(18.5 \mathrm{~g})$ was subjected to vacuum liquid chromatography over silica gel using a gradient elution mixture of $n$-hexane-EtOAc (10:0$0: 10$ ) as eluting solvents to afford 10 fractions (A$\mathrm{H})$. Fraction $\mathrm{C}(2.5 \mathrm{~g})$ was subjected to column chromatography over silica gel using a mixture of $n$-hexane:EtOAc (7:3) as eluting solvents to afford 6 fractions (C01-C06). Fraction C04 (85.5 mg) was subjected to column chromatography over silica gel using a mixture of $n$-hexane: $\mathrm{Me}_{2} \mathrm{CO}$ (7:3) to give 5 fractions (D01-D05). Fraction D03 was separated by preparative TLC on silica gel $\mathrm{GF}_{254}$ using a mixture of $n$-hexane: $\mathrm{Me}_{2} \mathrm{CO}(2: 3)$ to give (Figure 1) (12.8 mg).

Stigma-4-ene-3-on (Figure 1). IR $v_{\max }\left(\mathrm{cm}^{-}\right.$ $\left.{ }^{1}\right)$ : 3050, 2960, 2830,1710 and 1606; ${ }^{1} \mathrm{H}$ NMR (500 $\left.\mathrm{MHz}, \mathrm{CDCl}_{3}\right)$, Table $1 ;{ }^{13} \mathrm{C} \mathrm{NMR}(125 \mathrm{MHz}$, $\left.\mathrm{CDCl}_{3}\right)$ Table 1; MS $\left(\mathrm{m} / \mathrm{z} 413.3573[\mathrm{M}+\mathrm{H}]^{+}\right)$.

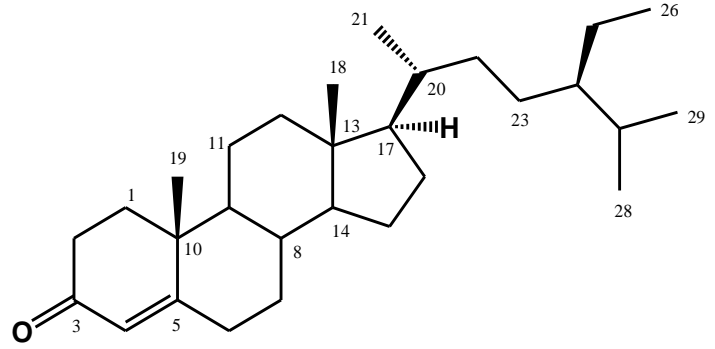

Figure 1. Chemical structure of stigma-4-en-3-on (1)

\section{RESULTS AND DISCUSSION}

Stigma-4-en-3-on(1) was obtained as a
white crystals and dissolve in
chlorofom.Liebermann-Burchard reaction of (Figure 1) gave a blue coloration, indicating a tetracyclic steroid. The molecular formula of (Figure 1) was established to be $\mathrm{C}_{29} \mathrm{H}_{48} \mathrm{O}$ based on HRTOFMS spectra $\left(\mathrm{m} / \mathrm{z} 413.3573[\mathrm{M}+\mathrm{H}]^{+}\right.$and NMR spectral data (Table 1), thus requiring six degrees of unsaturation. The IR spectrum showed strong absorption bands at 3150, 2960, 2870, and $1648 \mathrm{~cm}^{-1}$ which were due to an olefinic, aliphatic hydrocarbon and conjugated carbonyl groups. The ${ }^{1} \mathrm{H}$ NMR spectrum of (Figure 1) indicated the presence of two tertiery methyl at $\delta_{\mathrm{H}} 0.64$ and 1.11 , three secondary methyl at $\delta_{\mathrm{H}} 0.74(3 \mathrm{H}$, d, $J=6.7 \mathrm{~Hz}), 0.77(3 \mathrm{H}, \mathrm{d}, J=2.64 \mathrm{~Hz})$ and $0.84(3 \mathrm{H}$, $\mathrm{d}, J=6.54 \mathrm{~Hz})$, one primary methyl at $\delta_{\mathrm{H}} 0.77(3 \mathrm{H}$, $\mathrm{d}, J=6.5 \mathrm{~Hz})$, one olefinic proton at $\delta_{\mathrm{H}} 5.65(1 \mathrm{H}, \mathrm{s})$ and remaining $\mathrm{sp}^{3}$ aliphatic protons at $\delta_{\mathrm{H}} 0.85-2.32$ ppm, indicating the presence of steroidal skeleton in (Figure 1).

The ${ }^{13} \mathrm{C}$-NMR spectrum showed twenty nine carbon resonances, which were classified by their chemical shifts, DEPT and the HMQC spectra as one carbonyl, two tertiary methyl, three secondary methyls, one primary methyl, one $\mathrm{sp}^{2}$ methine, one $\mathrm{sp}^{2}$ quartenary carbon, eleven $\mathrm{sp}^{3}$ methylene, seven $\mathrm{sp}^{3}$ methines, and two $\mathrm{sp}^{3}$ quartenary carbons. These functionalities accounted for two out of the total six degrees of unsaturation. The remaining four degrees of unsaturation were consistent with stigmastan 
steroidstructure(Cayme and Ragasa, 2004; Phongmaykin et al., 2008). In order to clarify the position of functional group in structure of (Figure 1), HMBC and COSY experiments were carried out and the results was shown in Figure 2. The ${ }^{1} \mathrm{H}-$ ${ }^{1} \mathrm{H}$ COSY spectrum of 1 showed correlations in C1-C2, C6-C7-C8-C9-C11-C12, C15-C16-C17 and C20-C21-C23-C24-C-25, supporting the presence of stigmastan steroidal structure.HMBC correlations between proton at $\mathrm{H}-2\left(\delta_{\mathrm{H}} 2.35\right)$ and $\mathrm{H}-4\left(\delta_{\mathrm{H}} 5.65\right)$ to $\mathrm{C}-3\left(\delta_{\mathrm{C}} 199.7\right)$ and $\mathrm{C}-5\left(\delta_{\mathrm{C}} 171.7\right)$, indicated that an $\alpha, \beta$-unsaturated carbonyl group was located at C-3, C-4 and C-5, respectively. A methyl signal at $\delta_{\mathrm{H}} 1.11$ was correlated to $\mathrm{C}-1$ $\left(\delta_{\mathrm{C}} 35.6\right), \mathrm{C}-10\left(\delta_{\mathrm{C}} 38.6\right)$, and $\mathrm{C}-9$ ( $\left.\delta_{\mathrm{C}} 52.8\right)$, whereas the another tertiary methyl at $\delta_{\mathrm{H}} 0.64$ was correlated to C-12 ( $\left.\delta_{\mathrm{C}} 39.6\right), \mathrm{C}-13\left(\delta_{\mathrm{C}} 42.4\right)$ and C$17\left(\delta_{\mathrm{C}} 56.1\right)$, indicated that two tertiary methyls were located at C-18 and C-19, respectively. A secondary methyl at $\delta_{\mathrm{H}} 0.74$ was correlated to C$17\left(\delta_{\mathrm{C}} 56.1\right)$ and $\mathrm{C}-20\left(\delta_{\mathrm{C}} 36.1\right)$, indicate that one of secondary methyl was located at C-21. Methyl signals at $\delta_{\mathrm{H}} 1.18$ and 0.77 were correlated to $\mathrm{C}-27$ $\left(\delta_{\mathrm{C}} 29.8\right)$, indicated that a gem-dimethyl group was located at C-27. A secondary methyl at $\delta_{\mathrm{H}} 0.81$ was correlated to $\mathrm{C}-25\left(\delta_{\mathrm{C}} 29.2\right)$ and $\mathrm{C}-24\left(\delta_{\mathrm{C}} 45.8\right)$, indicated that a ethyl group was located at C-24. The stereochemistry of (Figure 1) was determined by NOESY experiments(Figure 3). The NOESY cross-peaks observed between $\mathrm{H}-2$ and $\mathrm{CH}_{3}-10$, and between H-4, H-6 and $\mathrm{H}-7$, indicated $\beta-$ configuration of methyl group at $\mathrm{C}-10$. NOESY cross-peaks of $\mathrm{H}-16 / \mathrm{H}-17 / \mathrm{H}-20$ indicated $\beta$ configuration of $\mathrm{CH}_{3}-18$. This configuration was consistent of stigmastan steroid structure (Kolak et al., 2005).

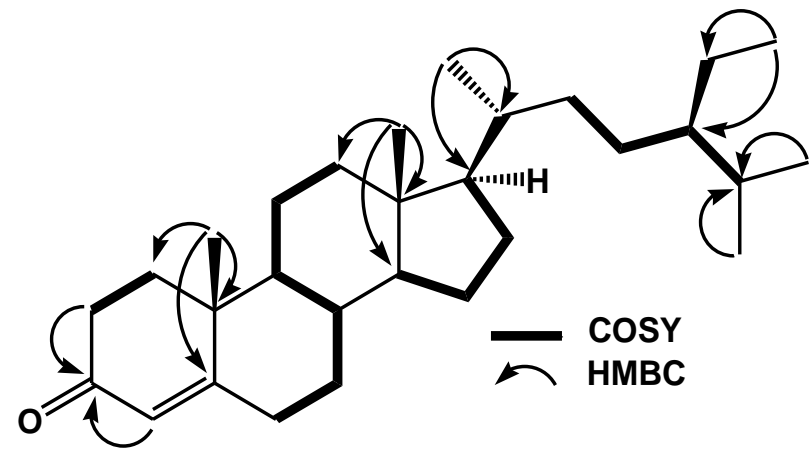

Figure 2. Selected HMBC and COSY correlations of stigmast-4-en-3-one(1)

Table 1. NMR data for compound 1 (500 MHz for ${ }^{1} \mathrm{H}$ and $125 \mathrm{MHz}$ for ${ }^{13} \mathrm{C}$ )

\begin{tabular}{|c|c|c|}
\hline $\begin{array}{c}\text { Position } \\
\text { of C }\end{array}$ & $\begin{array}{c}\delta_{\mathrm{H}} \\
{[\Sigma \mathrm{H}, \text { mult. } J(\mathrm{~Hz})]}\end{array}$ & $\delta_{\mathrm{C}}$ (mult.) \\
\hline \multirow[t]{2}{*}{1} & $1.62(1 \mathrm{H}, \mathrm{m})$ & $35.64(t)$ \\
\hline & $1.96(1 \mathrm{H}, \mathrm{m})$ & \\
\hline \multirow[t]{2}{*}{2} & $2.29(1 \mathrm{H}, \mathrm{m})$ & $34.00(\mathrm{t})$ \\
\hline & $2.35(1 \mathrm{H}, \mathrm{m})$ & \\
\hline 3 & - & $199.7(\mathrm{~s})$ \\
\hline 4 & $5.55(1 \mathrm{H}, \mathrm{s})$ & $123.7(\mathrm{~d})$ \\
\hline 5 & - & $171.7(\mathrm{~s})$ \\
\hline \multirow[t]{2}{*}{6} & $2.21(1 \mathrm{H}, \mathrm{m})$ & $32.9(\mathrm{t})$ \\
\hline & $2.32(1 \mathrm{H}, \mathrm{m})$ & \\
\hline \multirow[t]{2}{*}{7} & $0.96(1 \mathrm{H}, \mathrm{m})$ & $32.1(\mathrm{t})$ \\
\hline & $1.77(1 \mathrm{H}, \mathrm{m})$ & \\
\hline 8 & $1.44(1 \mathrm{H}, \mathrm{m})$ & $35.7(d)$ \\
\hline 9 & $0.85(1 \mathrm{H}, \mathrm{m})$ & $53.8(\mathrm{~d})$ \\
\hline 10 & - & $38.6(\mathrm{~s})$ \\
\hline \multirow[t]{2}{*}{11} & $1.22(1 \mathrm{H}, \mathrm{m})$ & $21.0(\mathrm{t})$ \\
\hline & $1.78(1 \mathrm{H}, \mathrm{m})$ & \\
\hline \multirow[t]{2}{*}{12} & $1.10(1 \mathrm{H}, \mathrm{m})$ & $39.6(\mathrm{t})$ \\
\hline & $1.97(1 \mathrm{H}, \mathrm{m})$ & \\
\hline 13 & - & $42.4(\mathrm{~s})$ \\
\hline 14 & $0.94(1 \mathrm{H}, \mathrm{m})$ & $55.8(d)$ \\
\hline \multirow[t]{2}{*}{15} & $1.38(1 \mathrm{H}, \mathrm{m})$ & $24.2(\mathrm{t})$ \\
\hline & $1.54(1 \mathrm{H}, \mathrm{m})$ & \\
\hline \multirow[t]{2}{*}{16} & $1.22(1 \mathrm{H}, \mathrm{m})$ & $28.2(t)$ \\
\hline & $1.78(1 \mathrm{H}, \mathrm{m})$ & \\
\hline 17 & $1.05(1 \mathrm{H}, \mathrm{m})$ & $24.2(\mathrm{~d})$ \\
\hline 18 & $0.64(3 \mathrm{H}, \mathrm{s})$ & $11.9(q)$ \\
\hline 19 & $1.11(3 \mathrm{H}, \mathrm{s})$ & $17.4(q)$ \\
\hline 20 & $1.28(1 \mathrm{H}, \mathrm{m})$ & $36.1(d)$ \\
\hline 21 & $0.74(1 \mathrm{H}, \mathrm{d}, 6.7)$ & $18.7(\mathrm{~d})$ \\
\hline \multirow[t]{2}{*}{22} & $0.94(1 \mathrm{H}, \mathrm{m})$ & $33.9(\mathrm{t})$ \\
\hline & $1.25(1 \mathrm{H}, \mathrm{m})$ & \\
\hline \multirow[t]{2}{*}{23} & $1.08(1 \mathrm{H}, \mathrm{m})$ & $26.1(\mathrm{t})$ \\
\hline & $1.09(1 \mathrm{H}, \mathrm{m})$ & \\
\hline 24 & $0.85(1 \mathrm{H}, \mathrm{m})$ & $45.8(\mathrm{~d})$ \\
\hline 25 & $1.60(2 \mathrm{H}, \mathrm{t}, 6.5)$ & $29.2(\mathrm{t})$ \\
\hline 26 & $0.84(3 \mathrm{H}, \mathrm{d}, 6.5)$ & $19.0(q)$ \\
\hline 27 & $1.18(1 \mathrm{H}, \mathrm{m})$ & $23.1(\mathrm{~d})$ \\
\hline 28 & $0.79(3 \mathrm{H}, \mathrm{d}, 2.6))$ & $19.8(q)$ \\
\hline 29 & $0.77(3 \mathrm{H}, \mathrm{d}, 2.6)$ & $11.9(\mathrm{q})$ \\
\hline
\end{tabular}

A detailed comparison of spectral data of 1 with those of previously reported, stigmast-4-en-3one (Kolak et al., 2005), revealed that both compounds showed very similar, consequently 
compound 1 was identified as a stigmast-4-en-3one and was shown for the first time in this species.

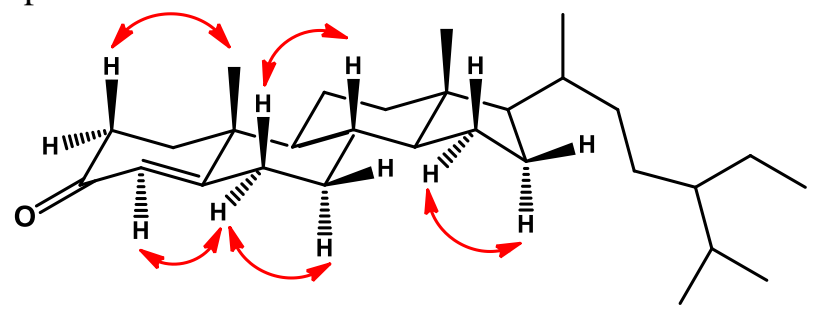

Figure 3. NOESY correlations of stigmast-4-en-3-one (1)

\section{CONCLUSION}

A stigmastane steroid, stigmast-4-en-3-one (1) has been isolated from the bark of Chisocheton lansiocarpus (Meliaceae). Its chemical structure was identified on the basis of spectroscopic datas and by comparison with previous data reported previously. Stigmast-4-en-3-one (1) was the first time isolated from Chisocheton lansiocarpusand give more information the occurance the stigmastane steroid in genus Chisocheton.

\section{ACKNOWLEDGEMENT}

This investigation was financially supported by Directorate General of Higher Education (PUPT by Nurlelasari). We thank Dr. Ahmad Darmawan, M.Si and Mrs. Sofa Fajriah, M.Si in the Research Center for Chemistry, Indonesian Science Institute for NMR measurements. We grateful Mr Kansi Haikal, S.Si in the Center Laboratory of Universitas Padjadjaran for HR-TOFMS measurement.

\section{REFERENCES}

Baskar, A.A., Al Numair, K.S., Paulraj, M.G., Alsaif, M.A., Al Muamar, $M$ and Ignacimuthu, S. 2012. $\beta$-Sitosterol prevents lipid peroxidation and improves antioxidant status and histoarchitecture in rats with 1,2dimethylhydrazine-induced colon cancer. Journal of Medicinal Food. 15: 335-343.

Bordoloi, M., Saikia, B., Mathur, R. K., Goswami, B. N., 1993. A meliacin from Chisocheton panniculatus. Phytochemistry, 34: 583-584.
Cayme, J., and C. Ragasa. 2004, Structure elucidation of $\beta$-stigmasterol and $\beta$-sitosterol from Sesbaniagrandiflaora (Linn). Pers. and $\beta$-carotene from Heliotropiumindicum Linn by NMR spectroscopy, Journal of Kimika, 20: 5-12.

Chai, J. W., Kuppusamy, U.R and Kanthimathi, M.S. 2008, $\beta$-sitosterol induces apoptosis in MCF-7 cells, Malaysian Journal of Biochemistry Molecular Biology, 16: 28-30.

Inada, A., Sukemawa, M., Murata, H., Nakanishi, T., Tokuda, H., Nishino, H., Iwashima, Darnaedi, D., J and Murata, J., 1993, Phytochemical studies on Maleaceous Plant. Part VIII. Structures and Inhibitory Effects on Epstein-Barr Virus Activation of Triterpenoida from Leaves of Chisocheton macrophyllus King, Chem. Pharm Bull, 41(3): 617-619.

Gupta A., Sharma, A.K., Dobhal, M.P., Sharma, M.C. and R. S. Gupta, 2011, Antidiabetic and antioxidant potential of $\beta$-sitosterol in treptozotocin-induced experimental hyperglycemia, Journal of Diabetes, 3: 2937.

Jamaluddin F., Mohamed, S., Lajis, M.N. 1994. Hypoglycaemic effect of Parma speciosa seeds due to the synergistic action of $\beta$ sitosterol and stigmasterol, Food Chemistry, 49: 339-345.

Ju, Y. H., Clausen, L.M., Allred, K.F., Almada, A.L and Helferich, W.G, 2004, $\beta$-sitosterol, $\beta$-sitosterol glucoside, and a mixture of $\beta$ sitosterol and $\beta$-sitosterol glucoside modulate the growth of estrogen-responsive breast cancer cells In vitro and in ovariectomized athymic mice, Journal of Nutrition, 134: 1145-1151.

Kolak, U., Topcu, G., Birteksoz, S., Otuk, G., Ulubelen, A., 2005, Terpenoids and Steroids from the roots of Salvia blepharochlena. Turk, J. Chem, 29: 177-188.

Laphookhieo, S., Maneerat, W., Koysomboon, S., Kiattansakul, R., Chantrapromma, K. \& Syers, J.K., 2008, A Novel Limonoid from the seeds of Chisocheton siamensis. Can. J. Chem, 86: 205-208. 
Maneerat, W., Laphoohiero, S., Koysomboon, S., and Chantrapromma, K., 2008, Antimalarial, antimycobacterial and cytotoxic limonoid from Chisocheton siamensis, Phytomedicine, 15 : 1130-1134.

Moon E.J., Lee, Y.M., Lee, O.H., Lee, M.J., Lee, S.K. and Chung, M.H., 1999, A novel angiogenic factor derived from Aloe vera gel: $\quad \beta$-sitosterol, a plant sterol. Angiogenesis, 3: 117-123.

Mohamad, K., Hirasawa, Y., Litaudon, M., Awang, K., Hamid, A., Takeya, K., Ekasari, W., Widyawaruyanti, A., Zaini, N. C., and Morita, H., 2009, Ceramicines B-D, new antiplasmodial limonoids from Chisocheton ceramicus, Bioorganic \& Medicinal Chemistry, 17: 727-730.

Najmuldeen, I. A., Hadi, A. H. A., Awang , K., Mohamad, K., Ketuly, K.A., Mukhtar, M.R., Chong, S.L., Chan, G., Nafiah, M. A., Weng, N. S., Shirota, O., Hosoya, T., Nugroho, A. E., and Morita, H., 2011, Chisomicines A-C, Limonoid from Chisocheton ceramicus, J. Nat. Prod, 74: 1313-1317.

Ostlund, R.E., Mcgill, J.B., Zeng, C., Covey, D.F., Stearns, J. and Stenson, W.F., 2002, Gastrointestinal absorption and plasma kinetics of soy 5-phytosterols and phytostanols in humans, American Journal of Physiology and Endocrinol Metabolism, 282: 911-916.

Park, C., Moon, D.O., Rhu, C.H., Choi, B.T., Lee, W.H., Kim, G.Y. and Choi, Y.H., 2007, $\beta$ sitosterol induces antiproliferation and apoptosis in human leukemic U937 cells through activation of caspase-3 and induction of Bax/Bcl-2 ratio, Biological and Pharmaceutical Bulletin, 30: 1317-1323.

Phongmaykin, J., Kumamoto, T., Ishikawa, T., Suttisri, R., and Saifah, E., 2008, A New Sesquiterpene and Other Terpenoid Constituents of Chisocheton penduliflorus, Arch Pharm Res, 31: 21-27.

Prieto, J.M., Recio, M.C. and Giner, R.M., 2006, Anti-inflammatory activity of $\beta$-sitosterol in a model of oxazolone induced contactdelayed-type hypersensitivity, Boletín Latinoamericano y del Caribe de Plantas Medicinales y Aromáticas, 5: 57-62.
Radika, M.K., Viswanathan, P. and Anuradha, C.V., 2013, Nitric oxide mediates the insulin sensitizing effects of $\beta$-sitosterol in high fat diet-fed rats, Nitric Oxide, 32: 43-53.

Roy, A., and Sarat, S., 2006, Limonoids: Overview of significant bioactive triterpenes distributed in plants kingdom, Biol. Pharm. Bull., 29: 191-201.

Saeidnia, S., A. Manayi, A. R. Gohari, and M. Abdollahi. 2014. The Story of $\beta$-sitosterol A Review. European Journal of Medicinal Plants. 4(5): 590-609.

Ovesna Z., Vachalkova, A. and Horvathova, K. 2004. Taraxasterol and $\beta$-sitosterol: new naturally compounds with chemoprotective/chemopreventive effects. Neoplasma. 51: 407-414.

Tzouros, M., Bigler, L., Bienz, S., Hesse, M., Inada, A., Murata, H., Inatomi, Y., Nakanishi, T., Darnaedi, D., 2004. Two new spermidine alkaloids from Chisocheton weinlandii. Helv. Chim. Acta., 87: 14111425.

Wong, C. P., Shimada, M., Nagakura, Y., Nugroho, A. E., Hirasawa, Y., Kaneda, T., Awang, K., Hamid, A., Hadi, A., Mohamad, K., Shiro, M., and Morita, H. 2011. Ceramicines E-I, New Limonoids from Chisocheton Ceramicus. Chem. Pharm Bull.59: 407-411.

Yang, M. H., Wang, J. G., Luo, J. G., Wang, X. B., and Kong, L. Y. 2011. Chisopanins A-K, 11 new protolimonoids from Chisocheton paniculatus and their antiinflammatory activities. Bioorganic \& Medicinal Chemistry. 19: 1409-1417.

Yang, M. H., Wang, J. S., Luo, J. G., Wang, X. B., and Kong, L. Y. 2009. Tetranortriterpenoids from Chisocheton Paniculatus. J. Prod. 70: 1532-1532.

Vivancos, M. and Moreno, J.J. 2005. $\beta$-Sitosterol modulates antioxidant enzyme response in RAW 264.7 macrophages. Free Radical Biology and Medicine. 39: 91-97.

Vossen, V. D., H. A. M., and Umali, B. E. (Editors). (2002). Plant resources of southeast Asia no. 14 vegetable oils and fats, Prosea Foundation, Bogor, Indonesia. 150. 
Stigmastane-steroid from the bark of Chisocheton lasiocarfus (Meliaceae)

(Nurlelasari, Fajar Fauzi Abdullah, Nadya Thufailah, Rani Maharani, Desi Harneti, Ace Tatang Hidayat, and Unang

Zak A., Zeman, M., Vitkova, D., Hrabak, P. and Tvrzicka, E. 1990. $\beta$-sitosterol in the treatment of hypercholesterolemia. Cas Lek Cesk. 129: 1320-1323.
Zhang, F., Feng, H.E., Bin, W., Sheningg, C. \& Mian, Y. 2012. New Apotirucallane Type Triterpenoid from Chisocheton paniculatus. Nat. Prod. Bioprospect. 2: 235-239. 